\title{
Exonation Clause in Financing Agreement (Study at Adira Sumbawa)
}

\author{
Zainal Abidin Djumardin Eduardus Bayo \\ Graduate Program Student in Notary, Faculty of Law, Mataram University, Indonesia
}

\begin{abstract}
This study aims to review and analyze legal protections for debtors and the legal consequences of credit agreements made with the exonation clause. The type of research used is normative empirical by using statutory, conceptual and sociological approach methods. Types and sources of data / legal materials are carried out using primary data in the form of field data and secondary data is related to the literature of legislation. Analysis of legal materials using qualitative analysis methods. Based on the results of the study, it is known that the legal protection of debtors against the implementation of the exonation clause in the credit agreement at adira finance institutions includes preventive protection and repressive protection. The legal consequences of credit agreements made with the exonration clause in the credit agreement at PT Adira Finance Sumbawa are null and void.
\end{abstract}

Keywords: Exhibitions, Agreements, Financing

DOI: $10.7176 / \mathrm{JLPG} / 112-10$

Publication date:August $31^{\text {st }} 2021$

\section{Introduction}

In the current Era of Globalization, Indonesia is actively conducting development in all fields, both in the economic, social, cultural and political fields. The development is intended to catch up with developed countries. Therefore, the Government's participation in fully supporting the development of financing business by providing various facilities and trying to involve this field of business in various development activities that are being encouraged. In addition, community participation is also very important for the implementation of economic development that is expected to have a large influence, especially the private sector.

The availability of funds for investment is formally channeled through financial intermediaries (financial institutions), both banks and other non-bank financial institutions. One of the business fields of financing institutions that are growing rapidly today is the consumer financing business. In this business, the financing company conducts efforts in financing the credit of consumer goods. The main thing that the financing company does is bind consumers who will apply for consumption credit with an agreement.

In consumer financing agreements, the agreement used is the standard agreement. This means that the company has determined the contents of the agreement, terms, conditions including the rights and obligations of the parties, so that no opportunity is provided for consumers to discuss the contents of the agreement. Consumers are only given the option to agree to the contents of the agreement or not to agree. Signing is a sign of agreement on the content of the agreement.

In the standard agreement, the principle of freedom of contract is less recognized. The default agreement arises due to unbalanced relations between the parties. thus triggering the higher-ranking party to do things that put pressure on the other party that is in a weak position. It was this situation that triggered the birth of covenants in the standard form. The default agreement is made unilaterally by one of the parties who has a stronger position. Thus the terms, conditions and contents and agreements have been predetermined by the stronger party.

In practice, businesses do not hesitate to set an exonration clause not only that reduces liability but often frees itself from responsibility or transfer of responsibility whose purpose is to lead to profit acquisition so that it is neglected consumer rights. Standard agreements are found in banking activities and other agreements such as financing institutions, trade and so on. In connection with this, various laws and regulations were held and in its latest development has been ratified by the government in the form of Law No. 8 of 1999 on Consumer Protection (hereinafter referred to as the Consumer Protection Law) in order to provide protection to consumers in general both against the use of goods and services products.

In each contract, both in the pre-contract stage and when the contract maker must contain the good faith of both parties. The good faith of the agreement can be seen from the content of the contract, and the arrangement of the rights and obligations of each party must be balanced. ${ }^{1}$ What has been explained earlier in the consumer financing agreement made on the basis of freedom of contract must also be made in good faith. In addition to being made in good faith in the making of consumer financing agreements must also pay attention to the provisions stipulated in Article 18 of Law No. 8 of 1999 concerning Consumer Protection (UUPK) that is about standard clauses that are prohibited to be included in a deed or agreement, the problem in the standard agreement

${ }^{1}$ H.R. Daeng Naja, Contract Drafting, PT. Citra Aditya Bakti, Bandung, 2006, hal. 15 
is not in the standard agreement, malainkan the absence of standard contracts (standard contracts) that are exonrated (exonerasi clauses).

Financing credit agreement at PT. Adira Sumbawa Branch is a standard agreement where the clauses of the agreement have been prepared in advance by PT. Adira Sumbawa Branch that consumers must comply with all requirements and conditions set by businesses in the implementation of credit agreements. the provisions and terms outline govern the risks that must be borne by consumers if lost, the obligation of consumers to hand back motor vehicle goods by determining fines in the event that consumers are negligent or late in returning goods, and the cost of returning goods borne by consumers, as well as the termination of unilateral leases made by businesses without waiting for a judge's decision if the business considers the consumer has committed negligence.

The privity principle of contract states, businesses / creditors have an obligation to protect consumers / debtors, but this can be done if between them established a contractual relationship. Businesses cannot be blamed for things beyond what is promised. That is, the debtor can sue based on contractual liability. However, although juridically often stated between businesses and consumers of the same position, but the fact that consumers are parties that are usually always dictated according to the will of businesses / creditors. Businesses can unilaterally eliminate the obligations that they should bear. As a result, if consumers sue businesses for "minor" mistakes, businesses can quibble. Such types of errors are not covered by the agreement. ${ }^{1}$ The imbalance of the use of standard agreements in credit agreements has an impact on the protection of unilateral rights to creditors rather than debtors, resulting in more risks or losses that must be borne by the debtor. This is undesirable and unjustified, because the law aims to give justice and protect all parties.

Based on the background above, the author is interested in researching on "LEGAL PROTECTION FOR DEBTORS AGAINST EXONERATED CLAUSES IN FINANCE FINANCING CREDIT AGREEMENTS (STUDY IN ADIRA SUMBAWA)".

\section{Research methods}

This study uses a type of research in empirical normative, namely looking at how the law works in society in solving a problem realized in the research on the effectiveness of the current law. To examine the problems in this study, approach techniques are used in the form of Statue Approach, Conceptual Approach, and Sociological Approach. $^{2}$

In the type of research used, among others, primary data, namely data that can be obtained through the search for legislation and field research, by conducting interviews with the Office of Adira Sumbawa Branch related to the exonation clause in the financing agreement. As well as secondary data, namely library materials, literature, previous research, books and so on.

The data source in this study was obtained directly from field research from a number of sources concerning information on legal protection for debtors against the exonation clause in credit agreements at the Adira finance agency Sumbawa.

The steps of collecting legal materials to be used are Library Materials and field data. The analysis of data and legal materials is done using qualitative methods that are by describing thoroughly the data produced during the research in search of clarity, the collected data is then analyzed using descriptive qualitative analysis, namely data obtained and presented in the form of descriptions to uncover the truth of the submitted data.

\section{Results and discussion}

3.1 Legal Protection against Debtors In The Implementation of Exonation Clauses on Credit Agreements At Adira Finance Sumbawa

The standard agreement made by Adira Finfance Sumbawa as a creditor can be classified as an act against the law because Adira Finfance Sumbawa as a creditor has made a credit agreement containing an exoneration clause, where the exonration clause is a prohibited clause stipulated in Article 18 of the Consumer Protection Law and Article 22 of POJK Number 1/POJK.07/2013 concerning Consumer Protection of the Financial Services Sector.

Conceptually, PT. Adira Finance Sumbawa is a financing company in which there is a standard agreement that has been made by the company. Such agreements are sometimes difficult for consumers to understand, so consumers prefer to sign them directly without reading and understanding the contents. Consumer Financing can be explained as financing activities for procurement of goods based on consumer needs with installment payment system or periodically by consumers. For now, the rise of credit purchases is most in demand by most people, because it is not burdensome to consumers. But consumers don't think about the impact that will have on those

\footnotetext{
${ }^{1}$ Milawartati T. Ruslan, Perlindungan Hukum Terhadap Konsumen dalam Perjanjian Pembiayaan Kendaraan Bermotor Roda Dua Berdasarkan Undang-Undang No. 8 Tahun 1999 tentang Perlindungan Konsumen, E Jurnal Katalogis, V 4, No. 10, 2016 , Hal. 208.

${ }^{2}$ Salim H.S dan Erlies Septiana Nurbani, Penerapan Teori Hukum Pada Penelitian Tesis dan Disertasi, Raja Grafindo Persada, Jakarta, 2013. Hal. 17-18
} 
who are harmed.

Regarding the content of the agreement made by the consumer finance company can be described as below.

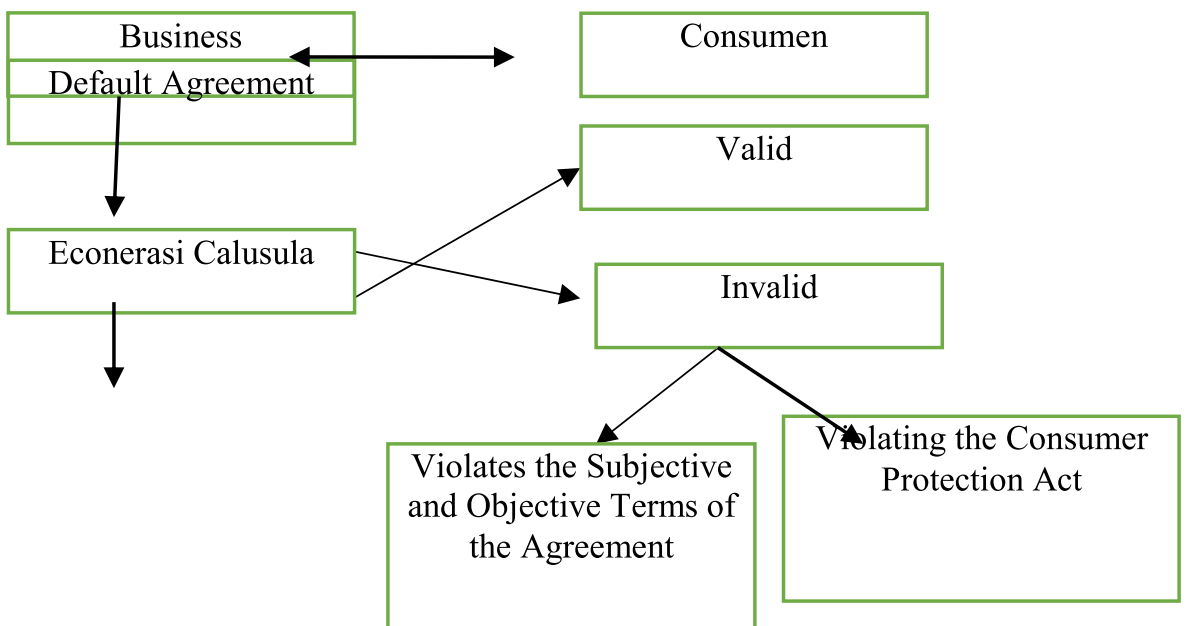

Figure 1. Consumer Financing Agreement Content Chart

From Figure 1, the author can describe that in the standard agreement of consumer financing credit there is an exonation clause that diverts and even removes the responsibility of the business. The standard agreement model that berklausula the exhibition, businesses have a strong economic position when dealing with consumers as buyers who are in a weak position. In practice, there are differences in the creation of standard clauses made by creditors. Each financing company has its own default agreement. Such as the standard agreement obtained by the author is the financing agreement of the financing company Adira Finance. The company has a standard agreement described as follows:

Adira financeagreement contains the terms of the agreement combined with the core articles of the agreement. The contents of the first agreement describe the biodata of the parties as debtors and credible. In Adira financeagreement there is a clause that explains about: 1) Contains Consumer Financing Object; 2) Contains The Structure of Consumer Financing; 3) Contains Fees. Meanwhile, the article of agreement basically consists of: Article 1 contains the Recipient of Consumer Financing Facilities; Article 2 contains data on goods and collateral; Article 3 contains the terms of the agreement which consists of Interest, Fines, Taxes, and Financing Costs, Rights and Obligations on Goods, Insurance, Injury of Promise, Expiration of Financing Agreement, Settlement of Disputes and contains Others. All the terms of the agreement have an explanation in the verses of each article of the agreement.

Based on the results of the author's interview to adira finance sumbawa employees, the scheme of consumer financing conducted by Adira finance is: ${ }^{1}$

a. Consumers come to the dealership to select the desired item and pay a down payment;

b. After the consumer obtains the desired goods the consumer submits an application to the financing company;

c. The task of the financing company to approve or disapprove the consumer's application with consideration of the state of the consumer economy;

d. The financing company pays the remaining payment or remaining consumer debt to the dealer on behalf of the consumer whose application is approved by the financing company;

e. After the dealer gets payment from the financing company and then the dealer sends the goods to the consumer according to the goods that have been selected by the consumer;

In Adira financeagreement there are 3 articles that each have verses. However, in this Adira financeagreement there are no terms of agreement, but in the Adira financing agreement the terms of the agreement have been listed in the articles of agreement. The author in conducting an analysis of this financing agreement does not do article-by-article analysis but rather analyzes the articles that the author thinks are important to analyze because of all the articles of the financing agreement Adira finance not all have irregularities.

The results of the research articles of the standard clauses of Adira financeagreements found to be contrary to the UUPK are presented in Table 1. as follows:

\footnotetext{
${ }^{1}$ Hasil wawancara kepada Agus kurniawan, Selaku MH (Marketing Head) Adira finance Sumbawa, pada tanggal 12 Maret 2021.
} 
Table 1. Results of Analysis of Raw Clause Content in Adira Finance Sumbawa Financing Company Related to Article 18 UUPK

\begin{tabular}{|l|l|l|}
\hline No & \multicolumn{1}{|c|}{ Contents of The Default Clause } & \multicolumn{1}{|c|}{ Information } \\
\hline 1. & $\begin{array}{l}\text { Article 3 paragraph 12 letter d "The creditor or his } \\
\text { representative is entitled to at any time, at the expense } \\
\text { / cost of the debtor to: i) enter the collateral; ii) check } \\
\text { the state of collateral; iii) perform or instruct the } \\
\text { debtor to do in accordance with letter c paragraph 11 } \\
\text { if the debtor is negligent and iv) place / make a mark } \\
\text { on the collateral that indicates the rights and interests } \\
\text { of the creditor }\end{array}$ & $\begin{array}{l}\text { Contrary to Article 18 paragraph (1) letter d } \\
\text { "Declaring the granting of power from } \\
\text { consumers to businesses either directly or } \\
\text { indirectly to take all unilateral actions related to } \\
\text { goods purchased by consumers in installments". }\end{array}$ \\
\hline 2. & $\begin{array}{l}\text { Article 3 paragraph 16 "The Debtor authorizes the } \\
\text { creditor with the right of substitution to manage the } \\
\text { disbursement of insurance claims, including but not } \\
\text { limited to receiving, signing the necessary documents } \\
\text { and approving/rejecting the results of insurance } \\
\text { claims from insurance companies." }\end{array}$ & $\begin{array}{l}\text { Contrary to Article 18 paragraph (1) letter d } \\
\text { UUPK which states businesses are prohibited } \\
\text { consumers to businesses either directly or } \\
\text { indirectly to take all unilateral actions related to } \\
\text { goods purchased by consumers in installments". }\end{array}$ \\
\hline
\end{tabular}

Source : Secondary data from the standard agreement of adira finance company

In the provisions of clause 3 paragraph 12 letter $d$ if observed there is an element of allowing creditors and / or their representatives to enter the debtor's house without the permission of the consumer. If this element is left and allowed, then the creditor will do or can take a unilateral action that can harm the debtor. For example creditors can confiscate collateral items without the debtor's knowledge.

It means that if observed clause in Article 3 paragraph 12 letter $\mathrm{d}$ gives the right to businesses to take unilateral action in the form of the act of entering the debtor's collateral without permission, so that if it is associated with the provisions of Article 18 paragraph (1) letter d UUPK, then clausea Article 3 paragraph 12 letter $\mathrm{d}$ is violated because the element of giving power to perform unilateral actions has been fulfilled.

Moreover, if the actions in Article 3 paragraph 12 letter d are related to the provisions of clause 3 paragraph 12 letter $\mathrm{f}$ then the actions of creditors can be very arbitrary to carry out confiscation of collateral goods and documents. Including after confiscation of collateral goods, creditors can make sales of collateral goods, which should not be able to foreclosure on collateral goods if the collateral is not registered as a fiduciary guarantee, but must go through the court to carry out execution in the form of foreclosure. Article 3 paragraph 12 letter $f$ of Adira financeagreement specifies:

The provisions of the above article in this Adira financeagreement clearly describe that the debtor only owns the goods as the economic owner who should be the absolute owner of the goods sold. If seen from Article 18 UUPK Article 4 paragraph (4) does not violate. However, judging from the good faith clause of Article 3 paragraph 11 in this financing agreement does not have an element of good faith because the right of ownership of goods that are actually in the hands of the debtor and the debtor can do anything to the goods he controls (sell, mortgage, rent) to be in the hands of creditors (because BPKB is controlled by creditors) so as to cause the debtor does not have the freedom to have rights to the goods he controls. In principle the law says this should not be (bad faith) as also stipulated in Article 1338 paragraph (3) of the Civil Code that an agreement should be implemented in good faith.

As explained earlier, the protection of debtors is divided into two, which are preventive and repressive. Preventive protection is a protection that prevents a problem, namely problems arising from the signing of a financing credit agreement. This protection is usually through legislation that contains mechanisms that guide the credit party (finance) and debtor so that at the time of implementation of the agreement does not cause problems. While repressive protection is the protection given to debtors after problems and tackling.

In connection with the azas-azas mentioned, the creation and implementation of financing credit agreements are also required to still refer to the basic principles of consumer protection. Therefore, there is no justification for a heavy contract standard. Both Adira financing institutions and debtors must realize that they have a balanced interest in each other, and for that they must cooperate in fair ways and with a fair division of rights and responsibilities as well.

Furthermore, in the protection that is repressive can be seen in Article 45 of the Consumer Protection Law that determines the form of dispute resolution that can be taken by consumers who feel harmed, the Article determines as follows:

a. Any aggrieved consumer can sue the business through the institution in charge of resolving disputes between consumers and businesses or through the judiciary that is in the general judicial environment.

b. Settlement of consumer disputes can be pursued through the courts or out of court based on the voluntary choice of the parties to the dispute.

c. Settlement of disputes outside the court as referred to in paragraph (2) does not eliminate criminal 
liability as referred to in paragraph (2) does not eliminate criminal liability as stipulated in the Law.

d. If an out-of-court consumer dispute resolution effort has been selected, a lawsuit through the courts can only be pursued if the attempt is declared unsuccessful by either party or by the parties to the dispute.

In addition, from the results of the author's interview to Iwan Satriawan said that if there is a dispute or dispute as a result of the implementation of the agreement between the creditor and the debtor then the parties have agreed to resolve it by deliberation and if the way of deliberation and consensus is not reached, then the parties agree to resolve it through the district court in the territory of the creditor or outside the court through alternative institutions of dispute resolution. ${ }^{1}$

In the loan agreement adira finance Sumbawa branch has determined that for all legal consequences regarding the credit agreement, the parties agreed to choose a common legal residence and remain in the clerk's office of the district court whose authority includes the territory where adira finance office gives credit. So that in this case the debtor can file a claim for damages against Adira finance Sumbawa Branch because it has committed an act against the law, the form of damages contained in Article 1365 of the Civil Code, Article 62 paragraph (1) of the Consumer Protection Law and administrative sanctions in Article 53 paragraph (1) POJK Number 1/POJK.07/2013 concerning Consumer Protection of the Financial Services Sector.

3.2 Due to The Law of The Existence of An Exonerated Clause On Credit Agreement At PT. Adira Finance Sumbawa

Due to the law for debtors in credit agreements in which there is an exonration clause at the Financing Office of Adira Finance Sumbawa branch, there is no legal certainty to the legislation, especially in providing protection of debtor rights and there are still violations of consumer rights due to the inclusion of the rules of the exonation clause in the credit agreement with the standard clause. Obligations and rights are antonyms in the law, so the obligation of businesses is a consumer right. In fact, consumer rights have been regulated in the UUPK. The indecision of the implementation of regulations on consumer rights will cause people, especially businesses, to exit the corridors of the established rule of law. This means that the rule has not been able to provide legal certainty.

As a result of the credit agreement law, the exconfyation clause for the debtor in the implementation of the credit agreement shall be subject to the terms and conditions of the agreement that has been unilaterally standardized by the creditor without any agreement between the parties regarding the credit and its credit rules.

The Financing Agreement at PT Adira Finance Sumbawa branch is a standard agreement made unilaterally by the company and consumers only have the option of taking the agreement or abandoning it. Then seen from the terms of validity of an agreement contained in Article $1320 \mathrm{KUH}$. Civil affairs that have been submitted above can be stated as follows:

Financing Agreement of PT Adira finance that has been made in writing, there is a binding agreement between the creditor and the debtor because it contains:

"On this day....... date....... made, agreed upon and signed by the Consumer Financing Agreement, hereinafter referred to as the "Financing Agreement", by and between the parties below "2

The word "agreed upon" means there is a will between the parties who enter into and make the agreement. The agreement has been solid, no longer in negotiations.

The statement of will or approval of the will must be the embodiment of free will meaning that there is no coercion and pressure from any party, must be corrected on the voluntary will of the parties. In it there is a principle of consensualism which is an agreement and an alliance that arises because it has been born since the moment of the achievement of the word agreement.

According to Article 1338 paragraph (1) it is determined that: "all agreements made valid as law to those who make it, anyone can be free to make any agreement as long as it does not violate or conflict with the applicable provisions." Which means that in the sentence "all covenants made legally" indicates the principle of freedom of contract. While the phrase "applies as law" indicates the principle of binding power or so-called pacta sunt servanda principle.

The binding power of the standard agreement is the same as the agreement in general, where the binding power has been born when the agreement between the parties, namely the debtor and creditor. Furthermore, the binding power of the standard agreement will expire when the agreement has been implemented or due to cancellation or null and void.

However, it can be seen again that the creation of the Financing Agreement of PT Adira finance has been made directly and is homogeneous which the agreement has been made in the form of many and consumers can not change the content of the agreement. Consumers only have the option of taking the agreement or leaving it (take it or leave it). Although it is undeniable that the contents of the agreement are still found to be contrary to or against the UUPK. This can be reinforced by the principle of freedom of contract whereby everyone is free to

\footnotetext{
${ }^{1}$ Hasil wawancara kepada Iwan Satriawan, selaku pegawai Kantor Adira Finanace Cabang Sumbawa, Pada tanggal 12 Maret 2021.

${ }^{2}$ Form Perjanjian Pembiayaan PT. Adira Finance
} 
make or not make any agreement, either that has been regulated by law or that has not been regulated by law. Freedom in this case is free in the form of its covenants as well as regarding the contents of the agreement.

The credit agreement made by the Financing Company of PT Adira finance, is made unilaterally and the contents have been determined by the company. Consumers cannot determine the contents of the agreement and consumers only agree because the agreement has been provided and made by the Financing Company of PT Adira finance and consumers only follow the procedure because consumers are interested in doing credit. In the principle of freedom of contract it is said that the parties are allowed to make their own agreements based on agreement and not contrary to law, public order and decency.

Freedom in this principle is not free as it is free, because the law provides its limitations, which contained in Article 1337 of the Civil Code which is a cause that is prohibited, if prohibited by law, or when contrary to either decency or public order. Restrictions can be by law, it can also be with government intervention, in the sense that not all individuals are free to determine the content of the agreement, for example by the existence of agreements of a standard or standard nature. Whether he has the authority to be entitled or act. Regarding the content of the agreement can be seen there is still harm to consumers because it is contrary to the Consumer Protection Act.

The agreement contained in the Financing Company of PT Adira finance is clearly done by someone / parties who have had proficiency. This can be known when doing the agreement has had identity and include a photocopy of ID card (Kartu Tanda Penduduk) so that the parties can be held accountable if there is something contrary in the future and the parties have legal proficiency.

The ability to make an agreement is further stipulated in Article 1329 of the Civil Code, which is that everyone is capable of making alliances if by law is not declared incapable. A person who is considered to have the ability to make a covenant is one who is capable of taking a legal action. Generally, those who are able to take legal action are people who have matured according to the law, people who are reasonable, not people who are under guardianship. Regarding the limit of maturity of a person is generally the person is said to be mature when he reaches the age of 21 years or is married, even though he is not yet 21 years old.

In making an agreement, the object of the agreement must be specific or at least can be determined according to the type of goods. This is as stipulated in Article 1333 of the Civil Code that an agreement must have a condition as the principal of an item, at least determined by its type. The meaning of a certain thing is that the object in the covenant must be about something particular. The object or achievement can at least be determined whether it is intangible or intangible. Because the object of the agreement is an achievement, the object of this agreement can be either giving something, doing something or not doing something. Thus, the object of the covenant is not always an object.

In the agreement between the consumer as the debtor and the Financing Company of PT Adira finance as the creditor there is a certain thing has been clearly stipulated in the contents of the agreement whose description is more detailed about the object until the fiduciary guarantee of the object.

Article 1332 of the Civil Code states that only tradable goods can be the subject of an agreement. In Article 1334 paragraph (1) of the Civil Code it is also stated that new goods will be present in the future can also be the subject of an agreement. Thus it is clear that the points of the agreement are existing goods or objects or goods or objects that will still exist.

An agreement without lawful reason will result in the agreement being null and void. So in addition to that the content of the agreement must be certain (can be determined), the content must also be halal (not forbidden), because the content of the agreement that will be implemented. The parties enter into an agreement with a view to carrying out the contents of the agreement under Article 1320 Jo. Article 1337 of the Civil Code. The content of the agreement shall not be contrary to law, decency and public order.

A lawful reason is the fourth and final requirement for the validity of a covenant. On this fourth condition Article 1335 of the Civil Code states that a covenant without cause or that has been made for a false or forbidden cause, has no power. The intent of the kausa is the content and purpose of the covenant itself.

Regarding the existence of a standard agreement as seen from the terms of validity of an agreement. The standard agreement in which there is an exhibition clause is contrary to the principle of freedom of contracting is responsible, because the position of the business person is higher than the position of the consumer and causes opportunities for businesses in abusing their authority. Businesses only regulate their rights, not even a few who bestow obligations on consumers. The standard agreement does not meet the conditions set forth in the Civil Code Article 1320 jo. Article 1338.

The agreement made by the Financing Company of PT Adira finance and consumers is contrary to the principle of contractual depravedness and has not fulfilled the elements contained in Article 1320 of the Civil Code, so there needs to be more stringent supervision so that the agreement is in accordance with and not contrary to the existing provisions. Plus the lack of sufficient consumer knowledge about the content of the agreement even consumers do not read or research the content of the agreement that can harm the consumer itself so, there is still found abuse of the standard agreement. Can be seen in the standard agreement the position of business actors looks more than the position of consumers. This can lead to opportunities for businesses in 
abusing their authority. Because businesses only regulate their rights and not a few bestow obligations on consumers. So it is still found in the agreement some clauses that are contrary to the UUPK. In response, there needs to be more stringent supervision in the making of the standard agreement.

Based on the previous explanation, an agreement is said to be valid when fulfilling the elements contained in Article 1320 of the Civil Code. The Agreement is fully binding on the parties if it is not contrary to law, decency, and public order. Some scholars have different opinions according to Abdulkadir Muhammad, the agreement has binding and coercive power. According to the Law, the party violating the agreement must pay compensation (article 1243 of the Civil Code), and bear the risk burden (article 1237 paragraph (2) of the Civil Code. ${ }^{1} \mathrm{He}$ stated that the agreement that has been made legally is binding on the parties, so that the agreement cannot be withdrawn or canceled unilaterally. Based on the previous explanation, an agreement is said to be valid when fulfilling the elements contained in Article 1320 of the Civil Code. The Agreement is fully binding on the parties if it is not contrary to law, decency, and public order. Some scholars have different opinions according to Abdulkadir Muhammad, the agreement has binding and coercive power. According to the Law, the party violating the agreement must pay compensation (article 1243 of the Civil Code), and bear the risk burden (article 1237 paragraph (2) of the Civil Code. ${ }^{2}$ He stated that the agreement that has been made legally is binding on the parties, so that the agreement cannot be withdrawn or canceled unilaterally.

Agreement contained in PT. Adira Finance, the author argues that the standard agreement does not meet the elements desired article 1320 jo. 1338 CIVIL CODE. In the standard agreement, it can be seen the difference in position between the entrepreneur and the consumer, where the consumer is not given the opportunity to make an offer on the agreement. Consumers do not have the freedom to express the will to determine the content of the agreement and contrary to the principle of freedom of contract. The agreement is take it or leave it so there is no bargaining in determining the content of the agreement. Although contrary to the principle of freedom of contract and this does not meet the elements required article 1320 jo. 1338 civil code, the agreement has no legal consequences or binding power if it is not fulfilled.

Standard agreements in which there is still an exconment clause are still often used in trading activities, and are growing especially in credit agreements found by the authors at PT. Adira Finance. This is due to its practicality and ease in making agreements.

The transfer of responsibility occurs due to an imbalance between pt's rights and obligations. Adira Finance and consumers. Addressing the condition of imbalance of regulation of rights and obligations between businesses (PT. Adira finance) and consumer 131 in the standard credit/contract agreement, with the enactment of UUPK until : ${ }^{3}$

1. The standard clause contained in the standard agreement / standard contract in which does not place the position of the consumer equivalent to the business actors are limitatively prohibited or at least limited, either about the content (Article 18 paragraph (1) letter a s.d. h) or the location or form is difficult to see or can not be read clearly or the disclosure is difficult to understand (Article 18 paragraph (2)).

2. Businesses are required to be held legally accountable, because in fact every standard clause in the standard agreement / standard contract that is contrary to this law is declared null and void and businesses are obliged to adjust it as stated in Article 18 paragraphs (3) and (4).

3. Business actors are required to be responsible under Article 19 paragraph (1) to paragraph (5) in which there is material and immaterial compensation.

4. Business actors can be penalized, either in the form of a maximum of 5 (five) years or a criminal with a maximum of Rp.2.000.000.000,00- (two billion rupiah).

Law No. 8 of 1999 on Consumer Protection has been published very clearly, but the implementation process has not been maximized, in other words the regulations contained in this Consumer Protection Law are not in accordance with the practice of public life. Generally the responsibility of businesses in the standard agreement is only limited to what has been promised and written in the standard agreement. In Article 18 UUPK, governing the prohibition for businesses, therefore the entrepreneur in this case is PT Adira finance is also responsible for violations committed against Article 18 UUPK moreover the violation is detrimental to the consumer.

That is, the standard agreement is recognized for its existence and does not violate the laws and regulations, if it does not have the exconneration clause mentioned in Article 18 of the UUPK. If in the standard agreement found clauses listed in Article 18 UUPK (exconneration clause), then the clause may be null and void. The existence of standard agreements in the community has been very inherent, especially for businesses. The existence of standard agreements of businesses can save time and implement agreements efficiently. The problem, however, is the content of the standard agreement. Making a unilateral standard agreement in this case business actors, then businesses may use the clauses contained therein to release responsibility and even transfer

\footnotetext{
${ }^{1}$ Abdulkadir Muhammad, Hukum Asuransi Indonesia, PT. Citra Aditya Bakti, Bandung, 2006, hal. 65.

${ }^{2}$ Abdulkadir Muhammad, Hukum Asuransi Indonesia, PT. Citra Aditya Bakti, Bandung, 2006, hal. 65.

${ }^{3}$ H.P. Panggabean, Praktik Standard Contract (Perjanjian Baku) dalam Perjanjian Kredit Perbankan, Alumni, Bandung, 2012 , hal. 9.
} 
responsibility to consumers. This is one of the triggers of the question of the use of standard agreements in businesses and businesses. If the consumer does not have enough knowledge and understands the content of the standard agreement provided by the business, then it can cause its own losses for consumers. In fact, most people do not read carefully a standard agreement before it is signed or ratified. It can trigger abuse or arbitrariness of businesses in making the content of standard agreements.

\section{Conclusion}

The legal protection of debtors against the implementation of the exonration clause in credit agreements at Adira finance institutions includes preventive protection and repressive protection. Preventive protection is intended to prevent the occurrence of a problem / dispute arising from the credit agreement, preventive protection is contained in Article 2 of the Consumer Protection Law, namely consumer protection based on benefits, fairness, balance, security, and safety of consumers, as well as legal certainty. Furthermore, in repressive protection, such protection is given to debtors after a problem and is to overcome it, namely in Article 45 paragraph (1) of the Consumer Protection Law, that any harmed consumer can sue businesses through institutions in charge of resolving disputes between consumers and businesses or through the judiciary that is in the general judicial environment, in addition to repressive protection contained in the adira Finance financing credit agreement in Article 3 Number 21 which states if a dispute arises or disputes as a result implementation of this agreement, then the parties agree to resolve it by deliberation, if the way of deliberation and consensus is not reached then the parties agree to resolve it through the district court in the territory of the creditor's office or out of court through an alternative dispute resolution institution that has been determined by the OJK.

Legal consequences of credit agreements made with the exonration clause in the credit agreement at PT Adira Finance Sumbawa, namely the legal consequences for violations of Article 1320 of the Civil Code, especially the terms of the halal kausa, then the agreement is null and void because it is contrary to Article 1337 of the Civil Code where the contents of the agreement have included the exconment clause in the standard agreement where it is contrary to Article 18 paragraph (1) and paragraph (2) of Law No. 8 of 1999 concerning Consumer Protection. On the other hand, the legal consequence of violation of Article 18 of the UUPK is that the agreement can be declared null and void and businesses must adjust it as stated in Article 18 paragraphs (3) and (4). Business actors in this case are PT. Adira Finance, can be penalized, either in the form of a maximum of 5 (five) years or a criminal with a maximum of Rp.2.000.000.000,00- (two billion rupiah).

\section{References}

Abdulkadir, M. (2006). Hukum Asuransi Indonesia. Bandung: PT Citra Aditya Bakti.

Naja, H. D., SH, M., \& Kn, M. (2006). Contract Drafting Seri Keterampilan Merancang Kontrak Bisnis. Citra Aditya Bakti.

Panggabean, H. P. (2012). Praktik standaard contract (perjajian baku): dalam perjanjian kredit pebankan. Penerbit PT Alumni.

Ruslan, M. T. (2016). Perlindungan Hukum Terhadap Konsumen Dalam Perjanjian Pembiayaan Kendaraan Bermotor Roda Dua Berdasarkan Undang-undang Nomor 8 Tahun 1999 Tentang Perlindungan Konsumen. Katalogis, 4(10).

Salim, H. S., \& Nurbani, E. S. (2013). Penerapan Teori Hukum Pada Tesis dan Disertasi. Jakarta: Rajagrafindo Persada. 